\title{
Reduction of C-Peptide Secretion in Noninsulin-Dependent Diabetic Patients with Long Duration of Insulin Treatment
}

\author{
Shiun Dong HSIEH $^{1}$, Yasuo AKANUMA ${ }^{1}$, Shoji KAWAZU ${ }^{2}$, Shigeru \\ MASHIKO $^{1}$, YASUNORI KANAZAWA ${ }^{1}$, YASUHIKo IWAMOTO ${ }^{1}$, \\ MASATOSHI KIKUCHI ${ }^{1}$ AND KinORI KOSAKA ${ }^{3}$ \\ ${ }^{1}$ Third Department of Internal Medicine, Faculty of Medicine, \\ University of Tokyo, ${ }^{2}$ Saitama Medical School, Saitama \\ and ${ }^{3}$ Toranomon Hospital, Tokyo
}

\begin{abstract}
We examined the responses of serum free C-peptide immunoreactivity (CPR) during a $100 \mathrm{~g}$ oral glucose tolerance test (OGTT) on diabetic patients undergoing different kinds and durations of treatment. None of the patients were ketosis-prone or had any history of nephropathy and they all developed diabetes when over the age of 30 . The $\Sigma$ serum free CPR (the sum of serum free CPR values during OGTT) of group A (duration of insulin treatment was less than 5 years, $N=10$ ) was found to be higher than that of group $\mathrm{B}$ (duration of insulin treatment was 5 years or more, $\mathrm{N}$ =10) $(\mathrm{p}<0.005)$. On the other hand, the $\Sigma$ serum free CPR of group C (treatment with an oral hypoglycemic agent for less than 5 years, $N=9$ ) was not statistically different from that of group $\mathbf{D}$ (treatment with an oral hypoglycemic agent for 5 years or more, $N=11$ ). There were no statistical differences between group $A$ and group $\mathrm{B}$ in age at onset, duration of diabetes, daily insulin dose, relative body weight index, serum creatinine or $\Sigma \mathrm{BG}$ (the sum of blood glucose values during OGTT). Just before the start of insulin treatment, there were no significant differences between the two groups in the following: 1. fasting blood glucose values (all 10 patients measured in group A and 9 patients in group B) 2 . blood glucose and plasma immunoreactive insulin (IRI) responses ( 7 patients measured in group A and 6 in group B). Among those with plasma IRI measured on the previous occasion, $\Sigma$ serum free CPR was found to be higher in group $A$ than in group $B(p<0.025)$ at the time of the present study. A negative correlation was noted between the duration of insulin treatment and $\Sigma$ serum free CPR in insulin-treated patients $(\mathrm{r}=-0.39, \mathrm{p}<0.05)$. Thus, pancreatic B-cell function in insulin-treated noninsulin-dependent diabetic patients is likely to be inversely correlated with the duration of insulin treatment.
\end{abstract}

Much work has been published supporting (Elahi et al., 1982; lijenquist et al., 1978; Beischer et al. 1978; Greenfield et al., 1981; DeFronozo et al., 1981) and arguing against (Ohagawara et al., 1973;

\section{Received April 12, 1983.}

This article is dedicated to the memory of Professor M. Kawakami, who wholeheartedly served as the chief editor of Endocrinologia Japonica.
Shima et al., 1977; Sando et al., 1970) the possibility of feedback inhibition of endogenous insulin secretion by exogenous insulin. Since C-peptide is secreted from pancreatic beta cells in equimolar concentrations with insulin (Rubenstein et al., 1969), measurement of serum C-peptide can reflect B-cell function in insulin-treated diabetic patients (Block et al., 1972). Un- 
fortunately insulin antibody can bind endogenously secreted proinsulin and greatly retard its clearanec from the blood. Furthermore, C-peptide is mainly metabolized in kidney (Katz and Rubenstein, 1973) and elevated during renatl failure (Regeur and Binder, 1976). Therefore, in this study, we have examined the residual beta cell secretory capacity in relation to the duration of insulin treatment in patients with noninsulin-dependent diabetes mellitus (NIDDM). We carefully considered the patients' relative body weight index, their serum creatinine level, the sum of blood glucose values during OGTT ( $\Sigma B G$ ) and clinical background before insulin treatment. We also examined the residual beta cell secretory capacity in relation to the duration of oral hypoglycemic agent treatment as a control study.

\section{Subjects and Methods}

\section{Subjects}

Subjects were selected from patients who had experienced fasting hyperglycemia (capillary blood glucose value $>140 \mathrm{mg} / \mathrm{dl}$ ) at least two times or more when over the age of 30 . All of them were within $120 \%$ of their ideal body weight calculated according to the formula of (body length in $\mathrm{cm}$ $100) \times 0.9$ in $\mathrm{kg}$ (Katsura, 1965), and without any history of renal disease or any other endocrinologic disease except for diabetes. All of them had had a serum creatinine level equal to or less than $1.4 \mathrm{mg}$ / dl within the past year.

The patients who were receiving insulin treatment were not ketosis-prone, and had had a history of diet or oral hypoglycemic agent treatment for one year or more before undergoing insulin treatment. According to the classification specified in the National Diabetes Data Group (1979), the patients belonged to the NIDDM group, but their treatment was changed to insulin for the control of hyperglycemia. The fasting blood glucose values before insulin treatment for group A $(215.3 \pm 64.0 \mathrm{mg} / \mathrm{dl}$, mean \pm S.D., $\mathrm{N}=10$ ) did not significantly differ from those of group $B(184.1 \pm 45.5 \mathrm{mg} / \mathrm{dl}, \mathrm{N}=9)$. The only missing value of fasting blood glucose in group B belonged to a patient who started insulin treatment during admission for pulmonary tuberculosis. Patients in the group undergoing oral hypoglycemic agent treatment had had no previous history of in- sulin treatment for the control of diabetes.

The patients were divided into 4 groups according to the duration and kind of treatment. Group $A$ had been treated with insulin for less than 5 years and consisted of 10 patients (age at onset 31$62 \mathrm{yrs}$, duration of diabetes 5-19yrs, duration of insulin treatment 1-4yrs). Group B had been treated with insulin for 5 years or more and consisted of 10 patients (age at onset 32-56 yrs, duration of diabetes 6-18 yrs, duration of insulin treatment 5-11 yrs). Group $\mathrm{C}$ had received oral hypoglycemic agent treatment for less than 5 years and consisted of 9 patients (age at onset 36-59yrs, duration of diabetes 1-13 yrs, duration of oral hypoglycemic agent treatment 1-4yrs). Group D had received oral hypoglycemic agent treatment for 5 or more years and consisted of 11 patients (age at onset 35-62 yrs, duration of diabetes 7-23 yrs, duration of oral hypoglycemic agent treatment 5-18 yrs).

\section{Procedures}

The patients were fasted overnight and went without medication until after being examined the following morning. Blood samples were taken from the antecubital vein before and after the oral administration of $100 \mathrm{~g}$ of glucose at intervals of $30,60,90$, 120 and 180 minutes. Sera were separated and stored at $-20^{\circ} \mathrm{C}$ until assay. Capillary blood for the measurement of glucose was collected from the ear lobe at corresponding times.

\section{Method}

Blood glucose was measured by a modification of Hoffman's method using a Technicon Autoanalyzer (Hoffman, 1937). Serum free C-peptide was assayed by pretreatment with polyethylene glycol (PEG) (Desbuquois and Aurbach, 1971; Kuzuya et al., 1977; Heding and Kasperska-Czyzykowa, 1980) and by the method (Oyama et al., 1977) in which a trace amount of sheep serum was added to adjust the standard curve to close to that without adding PEG. Sera from patients undergoing oral hypoglycemic agent treatment were also treated similarly with PEG for a comparison. The synthetic human C-peptide kit was supplied by Daiichi Radioisotope Laboratories (Tokyo).

\section{Sensitivity of assay}

The equation for the correlation between total and free C-peptide in sera of diabetic patients without insulin treatment was $\mathrm{Y}=1.022 \mathrm{X}+0.086(\mathrm{Y}=$ free CPR, $\mathrm{X}=$ total CPR, $\mathrm{N}=25, \mathrm{r}=0.969, \mathrm{p}<0.005)$. The coefficients of variation in intraassay were $7.4 \%$ $(0.71 \mathrm{ng} / \mathrm{ml}, \mathrm{N}=10)$ and $6.7 \%(2.99 \mathrm{ng} / \mathrm{ml}, \mathrm{N}=10)$. The coefficients of variation in interassay were 13.8 $\% \quad(1.08 \mathrm{ng} / \mathrm{ml}, \quad \mathrm{N}=10), \quad 7.5 \% \quad(3.20 \mathrm{ng} / \mathrm{ml}, \quad \mathrm{N}=10)$ and $12.5 \%(6.14 \mathrm{ng} / \mathrm{ml}, \mathrm{N}=6)$. The lower limit of the assay was $0.195 \mathrm{ng} / \mathrm{ml}$. 


\section{Statistics}

The sum of the six blood glucose values obtained before and after glucose load was represented as $\Sigma$ BG. The sum of serum free C-peptide immunoreactivities at the corresponding times was represented as $\Sigma$ serum free CPR. Data were compared using Student's $t$-test.

\section{Results}

The comparison of clinical data for group $\mathrm{A}$ and group $\mathrm{B}$ is shown in Table 1 .
¿Serum free CPR of group B $(11.76 \pm 2.94$ $\mathrm{ng} / \mathrm{ml}$, mean \pm S.D.) was significantly lower than that of group A $(17.64 \pm 4.72 \mathrm{ng} / \mathrm{ml})$ $(\mathrm{P}<0.005)$, although there were no significant differences between the two groups regarding age at onset, duration of diabetes, daily insulin dose, relative body weight index, serum creatinine value, or $\Sigma$ BG. There was a negative correlation between the duration of insulin treatment and $\Sigma$ serum free CPR $(\mathrm{r}=-0.39, \mathrm{p}<0.05$, as shown in

Table 1. Comparison of clinical data for groups A and B (mean \pm S.D.)

\begin{tabular}{|c|c|c|c|c|c|c|c|c|}
\hline Group & $\begin{array}{c}\text { Age } \\
\text { at onset } \\
(y r)\end{array}$ & $\begin{array}{l}\text { Duration } \\
\text { of } \\
\text { diabetes } \\
\text { (yr) }\end{array}$ & $\begin{array}{c}\text { Duration } \\
\text { of insulin } \\
\text { treatment } \\
\text { (yr) }\end{array}$ & $\begin{array}{l}\text { Insulin } \\
\text { dose } \\
\text { (u/day) }\end{array}$ & $\begin{array}{l}\text { Relative } \\
\text { body weight } \\
\text { index } \\
(\%)\end{array}$ & $\begin{array}{c}\text { Serum } \\
\text { creatinine } \\
(\mathrm{mg} / \mathrm{dl})\end{array}$ & $\begin{array}{c}\Sigma \mathrm{BG} \\
(\mathrm{mg} / \mathrm{dl})\end{array}$ & $\begin{array}{l}\sum \text { serum } \\
\text { free } \\
\text { CPR } \\
(\mathrm{ng} / \mathrm{ml})\end{array}$ \\
\hline A & 46.6 & 12.1 & 2.2 & 19.8 & 104.8 & 1.06 & 1524 & 17.64 \\
\hline $\mathrm{N}=10$ & $\frac{ \pm}{10.4}$ & \pm & $\begin{array}{l} \pm \\
1.3\end{array}$ & $\frac{ \pm}{6.8}$ & $\frac{ \pm}{6.2}$ & $\begin{array}{l} \pm \\
0.24\end{array}$ & 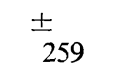 & \pm \\
\hline B & 46.2 & 13.5 & 7.7 & 21.1 & 102.3 & 0.92 & 1657 & 11.76 \\
\hline $\mathrm{N}=10$ & $\pm_{7.1}$ & $\pm_{4.3}$ & $\frac{ \pm}{2.5}$ & $\stackrel{ \pm}{15.4}$ & $\stackrel{ \pm}{6.5}$ & $\begin{array}{l} \pm \\
0.22\end{array}$ & $\frac{ \pm}{234}$ & $\stackrel{ \pm}{2.94}$ \\
\hline p-value & N.S. & N.S. & $<0.005$ & N.S. & N.S. & N.S. & N.S. & $<0.005$ \\
\hline
\end{tabular}

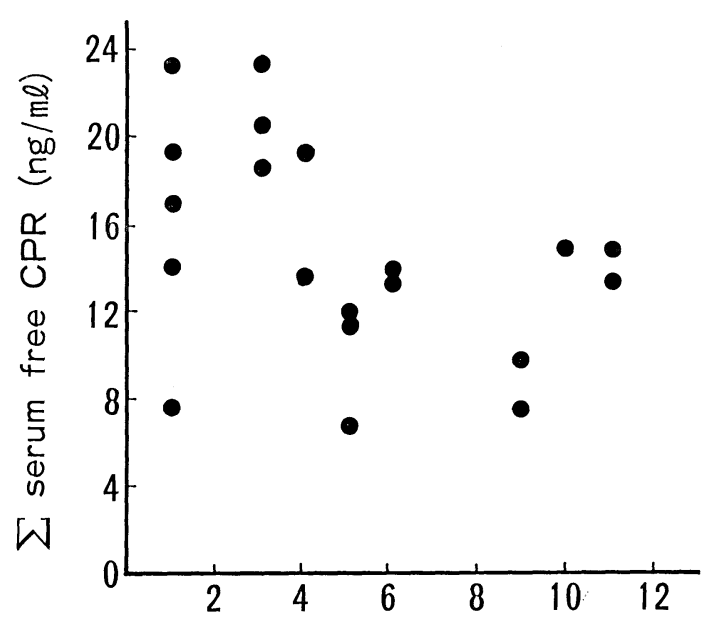

Duration of insulin treatment (yr)

Fig. 1. Correlation between duration of insulin treatment and $\Sigma$ serum free CPR in groups A and $\mathrm{B}(\mathrm{r}=-0.39, \mathrm{p}<0.05)$
Fig. 1). Blood glucose and plasma immunoreactive insulin (IRI) during the $100 \mathrm{~g}$ oral glucose tolerance test (OGTT) were measured in 7 patients from group $A$ and 6 patients from group B before the start of insulin treatment. The comparative data for group A ( 7 patients out of 10 were measured) and group B (6 patients out of 10) for the $100 \mathrm{~g}$ OGTT both before insulin treatment and at the present time of study are shown in Table 2. There was no statistical difference between the blood glucose responses of the two groups before insulin treatment and at the present time of study. Plasma IRI was also found to be not statistically different in the two groups before insulin treatment, although serum free CPR responses were found to be lower in group B than group A (significances were found at the intervals of fasting, $30 \mathrm{~min}$., $90 \mathrm{~min}$., $120 \mathrm{~min}$. and the sum of the six values.) 
Table 2. Comparison of $100 \mathrm{~g}$ OGTT data for groups A (7 out of 10 ) and B (6 out of 10) before insulin treatment and at the time of present study (mean \pm S.D.)

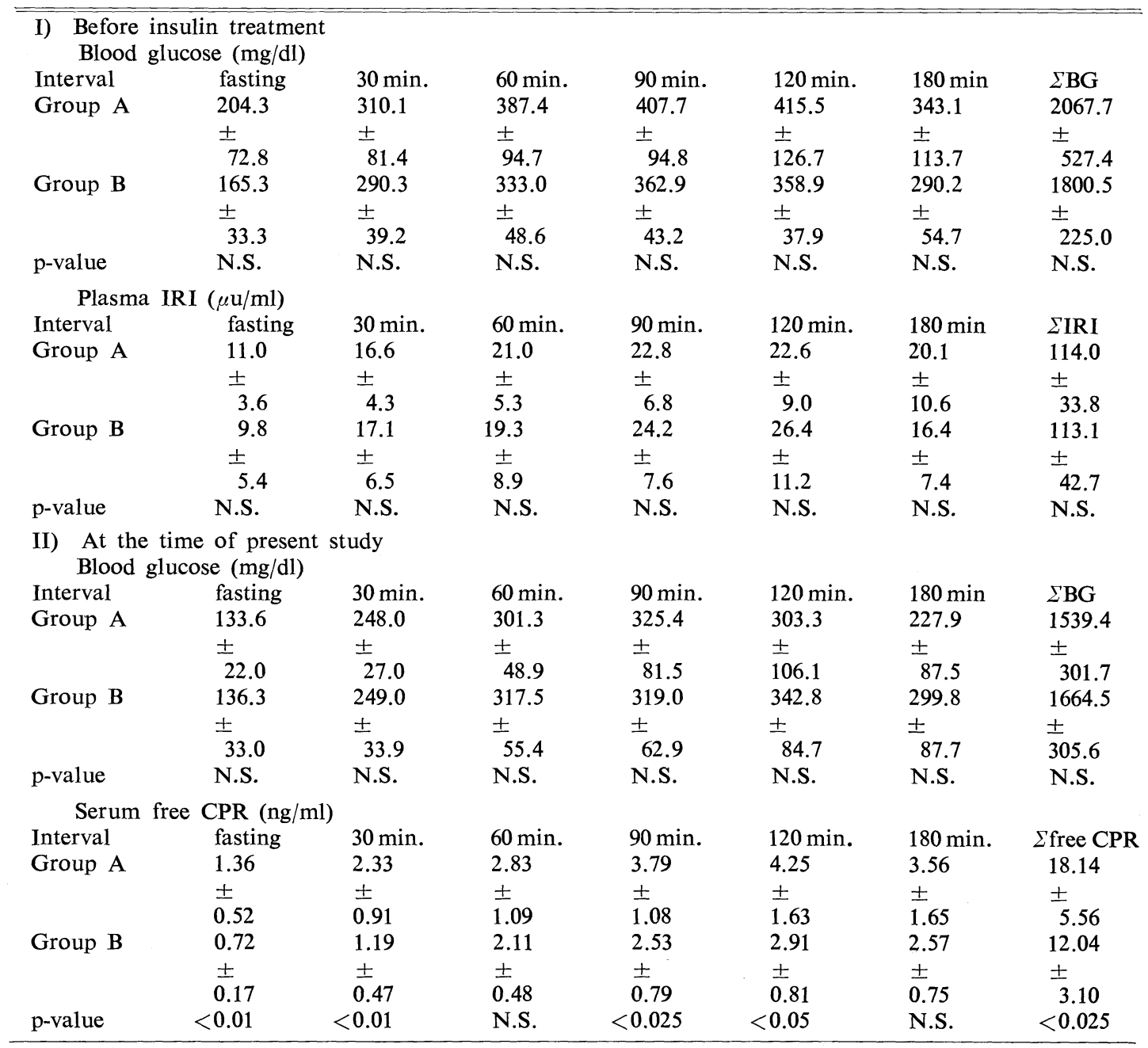

at the time of present study.

Comparative clinical data for group $\mathrm{C}$ and group D are shown in Table 3. There were no significant differences between the two groups in age at onset, relative body weight index, serum creatinine vablue, $\Sigma B G$ or $\Sigma$ serum free CPR, although the duration of diabetes and oral hypoglycemic agent treatment were longer in group D $(14.7 \pm 5.5$ yrs; $10.9 \pm 5.3 \mathrm{yrs})$ than in group $\mathrm{C}(6.3 \pm$ $4.2 \mathrm{yrs} ; 2.1 \pm 1.1 \mathrm{yrs})(\mathrm{P}<0.005)$. No statistical correlation was noted between the duration of oral hypoglycemic agent treatment and $\Sigma$ serum free CPR in patients in group $\mathrm{C}$ and group D (Fig. 2).

\section{Discussion}

There is still controversy concerning insulin therapy in islet founction although there is increasing evidence of feedback inhibition of endogenous insulin secretion by exogenous insulin. Based on a study of 
Table 3. Comparison of clinical data for groups $C$ and $D$ (mean \pm S.D.)

\begin{tabular}{|c|c|c|c|c|c|c|c|}
\hline Group & $\begin{array}{l}\text { Age } \\
\text { at } \\
\text { onset } \\
\text { (yr) }\end{array}$ & $\begin{array}{c}\text { Duration } \\
\text { of } \\
\text { diabetes } \\
\text { (yr) }\end{array}$ & $\begin{array}{l}\text { Duration of } \\
\text { oral hypo- } \\
\text { glycemic } \\
\text { agent } \\
\text { treatment } \\
\text { (yr) }\end{array}$ & $\begin{array}{c}\text { Relative } \\
\text { body } \\
\text { weight } \\
\text { index } \\
(\%)\end{array}$ & $\begin{array}{l}\begin{array}{c}\text { Serum } \\
\text { creatinine }\end{array} \\
(\mathrm{mg} / \mathrm{dl})\end{array}$ & $\begin{array}{c}\Sigma \mathrm{BG} \\
(\mathrm{mg} / \mathrm{dl})\end{array}$ & $\begin{array}{c}\begin{array}{c}\Sigma \text { serum } \\
\text { free }\end{array} \\
\text { CPR } \\
(\mathrm{ng} / \mathrm{ml})\end{array}$ \\
\hline $\mathrm{C}$ & 47.9 & 6.3 & 2.1 & 102.5 & 1.01 & 1440.8 & 17.80 \\
\hline $\mathrm{N}=9$ & $\stackrel{ \pm}{6.7}$ & \pm & \pm & $\begin{array}{l} \pm \\
12.2\end{array}$ & $\begin{array}{l} \pm \\
0.18\end{array}$ & \pm & \pm \\
\hline D & 48.4 & 14.7 & 10.9 & 99.1 & 1.03 & 1390.2 & 17.64 \\
\hline $\mathrm{N}=11$ & \pm & \pm & \pm & \pm & $\begin{array}{l} \pm \\
0.18\end{array}$ & \pm & \pm \\
\hline $\mathrm{p}$-value & N.S. & $<0.005$ & $<0.005$ & N.S. & N.S. & N.S. & N.S. \\
\hline
\end{tabular}

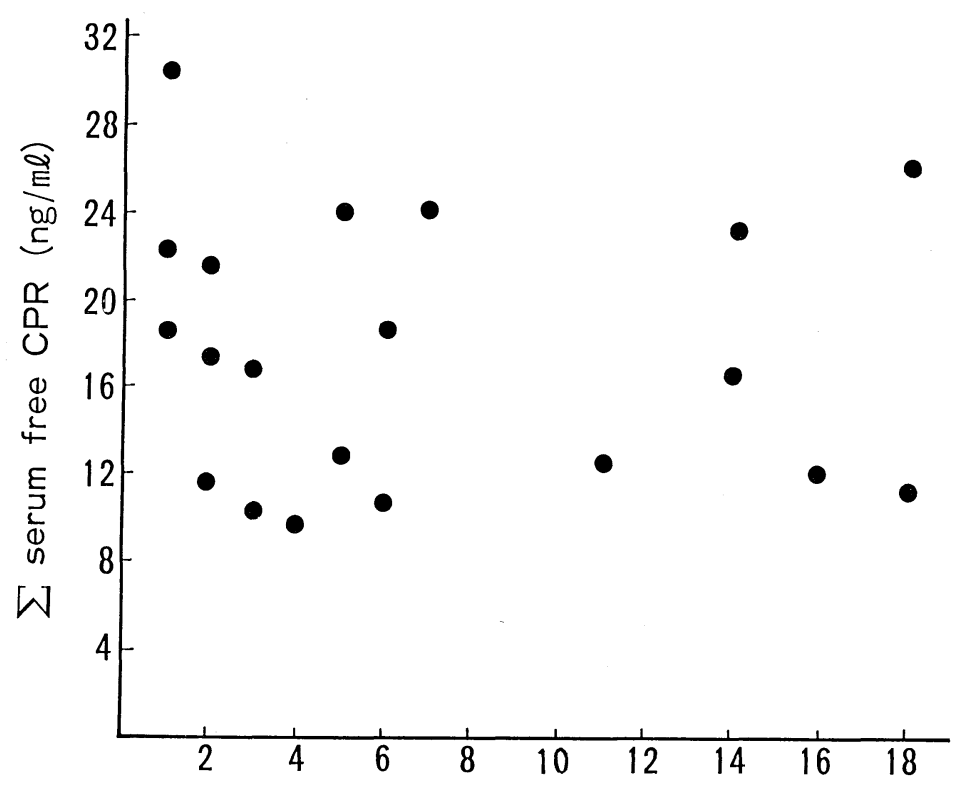

Fig. 2. Correlation between duration of oral hypoglycemic agent treatment and $\Sigma$ serum free CPR in groups C and D (N.S.)

Duration of oral hypoglycemic agent treatment (yr)

the preservation of residual beta cell secretion in insulin-treated patients, a significantly higher CPR level was demonstrated in the patients who had diabetes for less than 5 years (Binder and Faber, 1978; Grajwer et al., 1977; Ludvigsson and Heding, 1976; Hendrikson et al.; 1978). A similar correlation was found between short term ( 2 months to 2 years) and long term (5 to 8 years) insulin-dependent diabetic patients (Mirel et al., 1980). However, most of the above data dealt with patients with insulin-dependent diabetes mellitus (IDDM) who received insulin injections almost from the time of onset. Furthermore, pretreatment to remove proinsulin antibody complex was not mentioned by these authors. From the data, we cannot tell whether the decline in beta cell secretion was due only to a disease process or superimposed on the effect 
of insulin antibody or chronic suppression of endogenous secretion by supplying exogenous insulin.

Since the etiology might be different in NIDDM and IDDM, the disease process might be different too. We tried to study the reserve of $\mathrm{C}$-peptide secretory capacity in insulin-treated NIDDM patients and excluded those who had received insulin treatment soon after the onset. All the patients we studied had had a history of diet or oral hypoglycemic agent treatment for one or more years before undergoing insulin treatment and were not ketosis-prone. Impaired renal function can cause an elevation of serum C-peptide and mask the change in B-cell secretion (Kajinuma et al., 1979), while obesity can cause hypersecretion of insulin (Michael and David, 1967). Therefore, we tried to select patients with a relative body weight index of less than 120\% and serum creatinine equal to or less than $1.4 \mathrm{mg} / \mathrm{dl}$ so as to reduce the effects on the C-peptide concentration in serum. Insulin antibody can bind proinsulin giving a higher than actual level of CPR. Therefore to avoid this, we used PEG to precipitate antibody associated proinsulin. It has been reported that the standard curve of Cpeptide in the presence of PEG is superimposable on the curve for buffer alone (Kuzuya et al., 1977). However, we found differences between standard curves with and without PEG as outlined in another report (Heding and Kasperska-Czyzykowa, 1980). Therefore we added a small amount of sheep serum to adjust the standard curve so that it would be closer to the standard curve without adding PEG (Oyama et al., 1977). Since there is no cross immunoreactivity between human and sheep C-peptide, the above procedure does not affect the accuracy of the assay.

Although the clinical backgrounds and fasting blood glucose values before insulin treatment were similar in the insulin-treated groups, we found the decline of $\mathrm{C}$-peptide secretion during OGTT in the group having received insulin treatment for 5 or more years to be in agreement with other reports on IDDM patients while the duration of diabetes and daily insulin dose did not show any statistical difference between the two groups in our study. We have data on plasma IRI and blood glucose during OGTT before the start of insulin treatment in 7 out of 10 patients in group A and 6 out of 10 patients in group B. Their plasma IRI and blood glucose responses showed no statistical difference but when we compared the present serum free CPR responses between them, a lower value in the group treated with insulin for 5 or more years was still evident. Kosaka et al. (1980) demonstrated that plasma IRI responses could be increased similarly in overt maturity onset diabetic patients by means of diet, an oral hypoglycemic agent or short time insulin treatment. He suggested that the fall in the blood glucose values after treatment might be the result of increased endogonous insulin secretion or the cause of increased endogenous insulin secretion after metabolic improvement. From our study, we found no significant difference in blood glucose responses during oral glucose load between the short and long term insulin treated groups (Table 2). Thus, the metabolic factor has not affected our results. Barnes et al. (1974) reported that the increase in insulin output due to the action of chlorpropamide is transitory and only contributory in newly treated cases. In our study of oral hypoglycemic agent treated groups, there was also no correlation between the duration of oral hypoglycemic agent treatment and $\Sigma$ serum free CPR.

A negative correlation was noted between the duration of insulin treatment and $\Sigma$ serum free CPR in our study. This means that the residual C-peptide secretory capacity in NIDDM patients is likely to be inversely correlated to the duration of insulin treatment. Although strict control of blood glu- 
cose can cause an improvement in beta cell function (Mirouze et al., 1978), it has been reported (Madsbad et al., 1981) that there is an inevitable decline in beta cell function after the honeymoon period in spite of vigorous treatment administered to IDDM patients for some time intially. We do not know whether a greater physiological supply of exogenous insulin as artificial pancreas can prevent or prolong the occurrence of this process in insulin-treated NIDDM patients as mentioned concerning mild diabetic patients (Turner et al., 1976). Immune reaction may also play a role in the reduction of beta cell secretion (Grodsky, 1966; Lacy and Wright, 1965; Anderson, 1976). Another possibility is that with milder diabetic patients, there may be more chance of changing the treatment to something other than insulin within 5 years after insulin treatment and this makes a statistical difference in comparison of residual pancreatic B-cell function in short and long term insulin-treated groups. Anyway, we had similar clinical and laboratory backgrounds before insulin treatment in our studying groups, so that the possibility mentioned above did not seem to exist in our study. Thus, a reduction in free C-peptide secretion is likely to be related to the long duration of insulin treatment. However, a prospective study is necessary to clarify this further.

\section{Acknowledgments}

We are grateful to Prof. F. Takaku for his critical review of this manuscript and Dr. H. Kajinuma for giving us many helpful suggestions. We also thank Daiichi Radioisotope Laboratories, Tokyo, for kindly supplying the synthetic human C-peptide kit for our study.

\section{References}

Anderson, O. D. (1976). Clinical significance of antiinsulin antibodies. Acta Endocrinol. (Suppl.)
205, 231-204.

Barnes, A. J., K. J. T. Garbien, M. F. Crowley and A. Bloom (1974). Effect of short and long term chloropropamide treatment on insulin release and blood glucose. Lancet 2, 69-72.

Beischer, W., M. Schmid, W. Kerner, L. Keller and E. F. Pfeiffer (1978). Does insulin play a role in the regulation of its own secretion? Horm. Metab. Res. 10, 168-169.

Binder, C. and O. K. Faber (1978). Residual betacell function and its metabolic consequences. Diabetes 27 (Suppl. 1), 226-229.

Block, M. B., M. E. Mako, D. F. Steiner and A. H. Rubenstein (1972). Circulating C-peptide immunoreactivity: studies in normals and diabetic patients. Diabetes 21, 1013-1026.

DeFronzo, R. A., C. Binder, J. Wahren, P. Felig, E. Farrannini and O. K. Faber (1981). Sensitivity of insulin secretion to feedback inhibition by hyperinsulinemia. Acta Endocrinol. 98, 81-86.

Desbuquois, B. and G. D. Aurbach (1971). Use of polyethylene glycol to separate free and antibodybound peptide hormones in radioimmunoassay. J. Clin. Endocri. 33, 732-738.

Elahi, D., M. Nagulesparan, R. J. Hershcopf, D. C. Muller, J. D. Tobin, P. M. Blix, A. H. Rubenstein, R. H. Unger and R. Andres (1982). Feedback inhibition of insulin secretion by insulin; relation to the hyperinsulinemia of obesity. $N$. Engl. J. Med. 306, 1196-1202.

Grajwer, La., R. S. Pildes, D. L. Horwitz and A. H. Rubenstein (1977). Control of juvenile diabetes mellitus and its relationship to endogenous insulin secretion as measured by $\mathrm{C}$-peptide immunoreactivity. J. Pediatr. 90, 42-48.

Greenfield, M. S., L. Doberne, F. Kraemer, T. Tobey and G. Reaven (1981). Assessment of insulin resistance with the insulin suppression test and euglycemic clamp. Diabetes 30, 387-392.

Grodsky, G. M. (1966). Diabetes mellitus in rabbits immunized with insulin. Diabetes 15, 579-585.

Heding, L. G. and T. Kasperska-Czyzykowa (1980). C-peptide and proinsulin after oral glucose. Acta Med. Scand. Suppl. 639, 33-36.

Hendriksen, C., O. K. Faber, J. Drejer and C. Binder (1978). Prevalence of residual B-cell function in insulin-treated diabetics evaluated by the plasma C-peptide response to intravenous glucagon. Diabetologia 13, 280-288.

Hoffman, W. S. (1937). A rapid photoelectric method for the determination of glucose in blood and urine. J. Biol. Chem. 120, 51-55.

Kajinuma, H., Y. Kanazawa, H. Sando, M. Hayashi, S. Kawazu and K. Kosaka (1979). Human plasma C-peptide immunoreactivity: its correlation with immunoreactive insulin in diabetes and chronic liver and renal disease. Endocrinol. Japon. 26, 65-73.

Katsura, E. (1965). In: Theory and practice of diet 
therapy, 4th Ed., p 483. Editor: Iwatsuru, R., Nanzando, Tokyo in Japanese.

Katz, A. I. and A. H. Rubenstein (1973). Metabolism of proinsulin and C-peptide in the rat. $J$. Clin. Invest. 52, 1113-1121.

Kosaka, K., T. Kuzuya, Y. Akanuma and R., Hagura (1980). Increase in insulin response after treatment of overt maturity-onset diabetes is independent of the mode of treatment. Diabetologia 18, 23-28.

Kuzuya, H., P. M. Blix, D. L. Horwitz, D. F. Steiner and A. H. Rubenstein (1977). Determination of free insulin and C-peptide in insulin treated diabetics. Diabetes 26, 22-29.

Lacy, P. E. and D. H. Wright (1965). Allergic interstitial pancreatitis in rats injected with guinea pig antiinsulin serum. Diabetes 14, 634-642.

Lijenquist, J. E., D. L. Horwitz, A. S. Jennings, J. L. Chiasson, U. Keller and A. H. Rubenstein (1978). Inhibition of insulin secretion by exogenous insulin in normal man as demonstrated by Cpeptide assay. Diabetes $27,563-570$.

Ludvigsson, J. and L. G. Heding (1976). C-peptide in children with juvenile diabetes: a preliminary report. Diabetologia 12, 627-630.

Madsbad, S., T. Krarup, L. Regeur, O. K. Faber and C. Binder (1981). Effect of strict blood glucose control on residual B-cell function in insulindependent diabetes. Diabetologia 20, 530-534.

Michael, J. and M. K. David (1967). Plasma insulin responses to oral and intravenous glucose : studies in normal and diabetic subjects. J. Clin. Invest. 12, 1954-1962.

Mirel, R. D., F. Ginsberg-Fellner, D. L. Horwitz and E. J. Rayfield (1980). C-peptide reserve in insulin dependent diabetes. Diabetologia 19, 183-
188.

Mirouze, J., J. L. Selem, T. C. Phan, E. Mendoza and A. Orsett (1978). Sustained insulin in induced remissions of juvenile diabetes by means of an external pancreas. Diabetologia 14, 223-227.

National Diabetes Data Group (1979). Classification and diagnosis of diabetes mellitus and other categories of glucose intolerance. Diabetes 28, 1039 1057.

Ohgawara, H., K. Suzuki and K. Kosaka (1973): Effect of prior infusion of exogenous bonito insulin on glucose-induced insulin release in man. Endocrinol. Japon. 20, 307-313.

Oyama, H., M. Horino, Y. Nakashima, A. Tenko, S. Matsumura, S. Nishida and N. Nakazawa (1977). Free C-peptide immunoreactivity in insulin-treated diabetics. Endocrinol. Japon. 24, (2), 223-227.

Regeur, L. and C. Binder (1976). The correlation between plasma C-peptide and kidney function. Diabetologia 12, 416.

Rubenstein, A. H., J. C. Clark, F. Melani and D. F. Steiner (1969). Secretion of proinsulin C-peptide by pancreatic beta cells and its circulation in blood. Nature 224, 697-699.

Sando, H., Y. Kanazawa and T. Kuzuya (1970). Effect of bonito insulin on endogenous insulin secretion in dogs. Am. J. Phpsiol. 218, 1357-1362.

Shima, K., S. Morishita, N. Sawazaki, R. Tanaka and S. Tarui (1977). Failure of exogenous insulin to inhibit insulin secretion in man. Horm. Metab. Res. 9, 441-443.

Turner, R. C., S. T. McCarthy, R. R. Holman and E. Harris (1976). Beta-cell function improved by supplementing basal insulin secretion in mild diabetes. Br. Med. J. 1, 1252-1254. 